\author{
PATryk Nowicki, Monika Szymczak, Grzegorz Rosiński, Paweł Marciniak
}

\author{
Zakład Fizjologii i Biologii Rozwoju Zwierzat \\ Instytut Biologii Eksperymentalnej \\ Wydział Biologii \\ Uniwersytet im. Adama Mickiewicza w Poznaniu \\ Umultowska 89, 61-614 Poznań \\ E-mail: patryk.nowicki@amu.edu.pl
}

\section{NEUROPEPTYDOMIKA SYSTEMU NEU WSTEP}

Postęp jaki dokonał się w erze "omik" na przełomie XX i XXI w. spowodował przejście $z$ podejścia redukcjonistycznego, skoncentrowanego na poszczególnych strukturach molekularnych, do strategii zakładającej holistyczne spojrzenie na komórkę i organizm (LEGOCKI 2004). Mimo szerokich perspektyw wynikających $z$ poznania sekwencji genomu szeregu gatunków, kluczowym wydaje się być prowadzenie badań nad kodowanymi przez geny peptydami i białkami (HAIDER i PAL 2013). Wśród peptydów wyróżnia się bardzo istotna grupę zwiazków zwanych neuropeptydami. Sa to zwiazki, które należa do neuroaktywnych biomolekul, syntetyzowanych i wydzielanych przez komórki układu nerwowego. Ich obecność potwierdzono w ośrodkowym układzie nerwowym oraz wielu innych tkankach i narzadach zarówno organizmów kręgowych, jak i bezkręgowców (SKÖLD 2006). Należą do nich neurotransmitery, neuromodulatory i neurohormony. Neurotransmitery to substancje biologicznie czynne, które przenosza impulsy nerwowe pomiędzy neuronami, a także między neuronami a komórkami mięśniowymi lub gruczołowymi. Neuromodulatory sa czasteczkami, które łącząc się $z$ receptorami $\mathrm{w}$ błonie pre- i/lub postsynaptycznej moduluja neurotransmisje, ograniczajac lub nasilając syntezę i wydzielanie neurotransmiterów, czy regulując liczbę receptorów dla neurotransmiterów w błonie postsynaptycznej. Z kolei neurohormony to hormony syntetyzowane przez tkanke nerwowa, wydzielane przez komórki nerwowe, które działając lo-

\section{EUROENDOKRYNOWEGO OWADÓW}

kalnie oraz na odległość modyfikuja strukturę i czynność tkanek organizmu. Zdecydowana większość neuropeptydów odgrywa rolę neuromodulatorów, ale moga także pełnić funkcje neurotransmiterów i neurohormonów (DAHLIN 2005). Kompletny zestaw neuropeptydów kodowanych przez geny danego organizmu nazywamy jego neuropeptydomem. Rozdzielanie, identyfikacja oraz ocena struktury i funkcji neuropeptydów sa przedmiotem badań stosunkowo nowej gałęzi nauki określanej jako neuropeptydomika (FÄLTH i współaut. 2007). Profil neuropeptydów ulegających ekspresji zależny jest przede wszystkim od stanu fizjologicznego organizmu oraz warunków środowiska, w którym żyje. Obecnie główna technika stosowana $\mathrm{w}$ neuropeptydomice przy określaniu profilu neuropeptydowego jest spektrometria mas (ang. mass spectrometry, MS). Polega ona na wykrywaniu składu aminokwasowego peptydów w oparciu o stosunek masy do ladunku, uprzednio zjonizowanych atomów lub czasteczek. $Z$ tego powodu jest jedna $Z$ wiodących technik umożliwiających jakościową oraz ilościowa ocenę biosyntezy białek i peptydów (w tym neuropeptydów) ekstrahowanych $z$ tkanek, a także $z$ pojedynczych komórek owadzich.

Ze względu na podobieństwo funkcjonalne systemów owadzich do układów kręgowców, przedstawiciele tej gromady stanowia dogodny model do badań $\mathrm{w}$ zakresie funkcjonowania układu neuroendokrynowego, a także identyfikacji składowych neuropeptydomu (HARTENSTEIN 2006). Ponadto, wiele neuropeptydów owadzich wykazuje wyraźne podobieństwo zarówno pod względem struk- 
tury, jak i funkcji do odpowiedników występujacych u ssaków (NÄSSEL i WEGENER 2011). Identyfikacja neuropeptydów owadzich oraz poznanie ich działania może więc stworzyć naukowe podstawy do zaprojektowania peptydomimetyków wykorzystywanych w medycynie do leczenia chorób u ludzi. Peptydy działajace hamujaco na procesy zwiazane $z$ reprodukcja $i$ pobieraniem pokarmu, mogą znaleźć w przyszłości zastosowanie jako selektywne środki ograniczajace liczebność owadów szkodliwych dla człowieka $z$ medycznego lub gospodarczego punktu widzenia.

\section{UKŁAD NEUROENDOKRYNOWY OWADÓW - BUDOWA I FUNKCJE}

Neuropeptydy odgrywaja zasadniczą rolę w regulacji procesów fizjologicznych zarówno u owadów, jak i zdecydowanej większości pozostałych gromad zwierzat (HARTENSTEIN 2006). Ścisła integracja układu nerwowego i endokrynowego owadów, warunkuje kontrolę nad procesami krótkotrwałymi, np. reakcja walki lub ucieczki, oraz procesami długotrwałymi, związanymi ze wzrostem, dojrzewaniem czy metabolizmem (SCHMIDT-NIELSEN 2008). Główne narządy wewnątrzwydzielnicze owadów tworzą komórki neurosekrecyjne zlokalizowane w mózgu i zwojach brzusznego łańcuszka nerwowego, a także tkanki gruczołowe, m.in. ciała kardialne (łac. corpora cardiaca, CC), ciała przyległe (łac. corpora allata, CA) oraz gruczoly protorakalne (ang. prothoracic gland, PG). U muchówek CC, CA i PG skupione sa w jeden kompleks, zwany gruczołem pierścieniowym, który okala proksymalne zakończenie naczynia grzbietowego. Z kolei u przedstawicieli pozostałych rzędów owadów CC i CA sa oddzielnymi strukturami lub tworza kompleks bez gruczołu protorakalnego (NÄSSEL i WEGENER 2011). CC i CA oraz zakończenia komórek neurosekrecyjnych znajdujace się w bezpośrednim kontakcie $z$ naczyniem funkcjonuja jako narzad neurohemalny (AGUI i współaut. 1979, CARROW i współaut. 1981). Kluczowa struktura układu neuroendokrynowego, odpowiadajaca za synchronizację i koordynowanie procesów wydzielania wewnętrznego, jest mózg. W jego budowie wyróżnić można trzy części: przodomózgowie (łac. protocerebrum), śródmózgowie (łac. deutocerebrum) i tyłomózgowie (łac. tritocerebrum). Konektywy łaczace mózg ze zwojem podprzelykowym tworza tzw. obrączke okołoprzełykową (HARTENSTEIN 2006). Lokalizacja komórek neurosekrecyjnych w mózgu jest zróżnicowana, choć u wszystkich gatunków można wyróżnić większe ich skupienia. Jedno w grzbietowo-przyśrodkowej części protocerebrum - pars intercerebralis (PI) oraz po jednej grupie komórek w części bocznej mózgu - pars lateralis (PL).

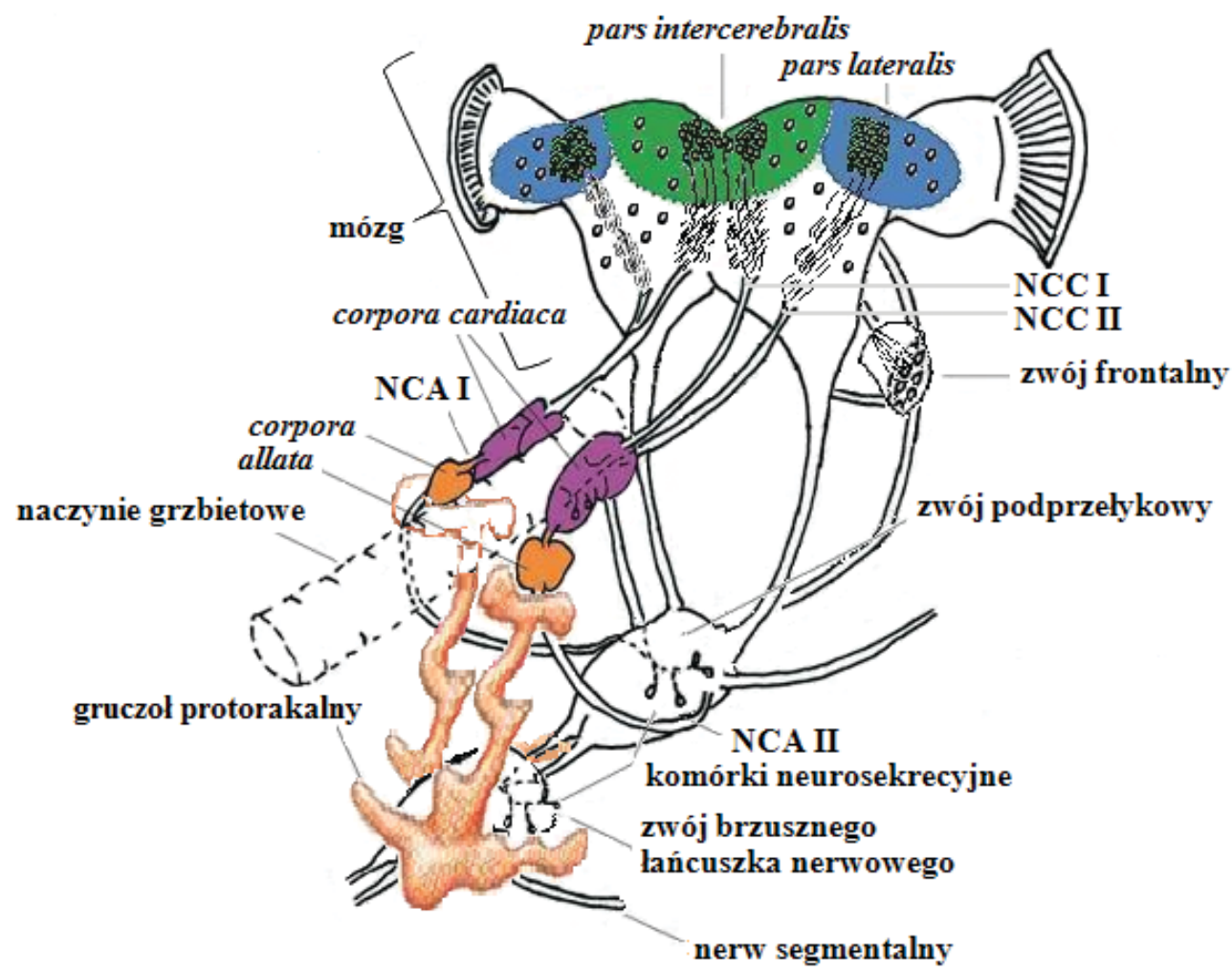

Ryc. 1. Schemat przedstawiający strukturę układu neuroendokrynowego owada (wg HARTENSTEIN 2006). 
Produkty komórek zlokalizowanych w PI i PL stanowiace neurosekret, transportowane sa do kompleksu retrocerebralnego $\mathrm{CC} /$ CA. Transport neurosekretu do CC przebiega od komórek intercerebralnych aksonami skupionymi w nervi corporis cardiaci I (NCC I) oraz aksonami komórek lateralnych tworzacych nervi corporis cardiaci II (NCC II). Z kolei bezpośrednie połaczenie między neuronami mózgu a CA zapewniaja nervi corporis allati I (NCA I), zaś ze zwojem podprzełykowym, CA łączą się poprzez nervi corporis allati II (NCA II) (Ryc. 1). W kompleksie retrocerebralnym nastepuje czasowa akumulacja neurohormonów, które następnie uwalniane sa do hemolimfy. CC oprócz funkcji magazynujacej zdolne sa do produkcji i wydzielania własnych hormonów (MARCINIAK i współaut. 2011). Układ neuroendokrynowy pełni kontrole nad prawidłowym przebiegiem procesów fizjologicznych, regulujacc homeostazę całego organizmu owada (KODRIK 2008). Regulacja ta oprócz indukowania procesu linienia i metamorfozy charakterystycznej dla owadów holometabolicznych przejawia się m. in. w kontroli uwalniania lub magazynowania lipidów i węglowodanów w ciele tłuszczowym (EWER i współaut. 1997, GÄDE i współaut. 1997). Wiele neuropeptydów wykazuje działanie miostymulujace bądź mioinhibicyjne, regulujac kurczliwość zarówno mięśni trzewnych, jak i somatycznych (Schoofs i NACHMAN 2006). Neuropeptydy odgrywaja również istotna rolę $\mathrm{w}$ regulacji behawioru oraz procesie poszukiwania i pobierania pokarmu (DILlen i współaut. 2013). Związki te odpowiadaja także za prawidłowy przebieg diurezy, transport jonów, sklerotyzację i melanizację kutikuli oraz procesy związane $z$ reprodukcja. Ponadto, jako kluczowe cząsteczki sygnalizacji neuroendokrynowej w sposób istotny wpływaja na regulację cyklu okołodobowego, odbiór sygnałów ze środowiska, reakcję na stres, zdolność uczenia i zapamiętywania oraz aktywność lokomotoryczną owadów. O wysokim stopniu specjalizacji układu neuroendokrynowego w koordynowaniu procesów życiowych u owadów świadczy fakt, że wiele neuropeptydów wykazuje plejotropowa funkcję fizjologiczna (MARCINIAK i współaut. 2011).

\section{KRYTERIA KLASYFIKACJI NEUROPEPTYDÓW OWADÓW}

Intensywne badania prowadzone w zakresie neuropeptydomiki owadów pozwoliły na identyfikację znaczacej liczby neuropeptydów, które pogrupowano w odrębne rodziny. Ze względu na możliwość modulowania licznych procesów fizjologicznych przez określony neuropeptyd, kategoryzację funkcjonalna zastapiono klasyfikacją strukturalną, opierająca się na podobieństwie sekwencji aminokwasowych (MARCINIAK i współaut. 2011). Zbliżona sekwencję aminokwasowa wykazuja peptydy, które powstały $z$ tego samego białka prekursorowego, kodowanego przez konkretny gen. Z uwagi na możliwość kodowania kilku biomolekuł przez jeden gen, liczba identyfikowanych neuropeptydów przewyższa liczbę genów niezbędnych do ich biosyntezy. Ponadto, u coraz większej liczby owadów identyfikowane sa kodowane przez te same geny bioanalogi, wykazujące nieznaczne różnice w sekwencji aminokwasów (ALTSTEIN i NÄSSEL 2010). Dodatkowo, w niektórych rodzinach neuropeptydowych, oprócz peptydów o kompletnej liczbie aminokwasów, zidentyfikowano formy skrócone, które również kodowane sa przez te same geny. Obecnie, dzięki dynamicznemu rozwojowi technik neuropeptydomiki, poznano sekwencje aminokwasowe ponad kilkuset neuropeptydów owadzich. Według obowiąujacej od 2010 r. nomenklatury strukturalnej pogrupowane sa one w 32 rodzinach neuropeptydowych (CoAST i SCHOOLEY 2010). Jak dotąd, skrócone formy $N$-terminalnie wydłużonych odpowiedników stwierdzono w przypadku przedstawicieli rodziny krótkich neuropeptydów $F$ (ang. short neuropeptides F, sNPF). Sa to w większości przypadków undekapeptydy, czyli peptydy składajace się $z$ jedenastu aminokwasów o konserwatywnym C-terminalnym motywie xPxLRLRFa. U Schistocerca gregaria zidentyfikowano dodatkowo dwie formy skrócone $N$-terminalnie o trzy aminokwasy. Jak wykazały badania, oktapeptydowa forma o identycznej sekwencji pojawia się także u wielu innych gatunków owadów, m.in. Apis mellifera czy Tribolium castaneum. Z kolei sekwencje form „kompletnych” u różnych gatunków różnią się trzema terminalnymi aminokwasami $\mathrm{N}$-końca. Prowadzone dotychczas badania wykazały, że formy: kompletna i skrócona moga w sposób istotny różnić się aktywnością fizjologiczna (DILLEN i współaut. 2013). Ze względu na postępujacy rozwój technik stosowanych w badaniach nad neuropeptydomem, zdefiniowana dotychczas przynależność peptydów do poszczególnych rodzin, może podlegać zmianom. Przykład stanowia wspomniane wcześniej neuropeptydy F, sNPF oraz miosupresyny, które początkowo traktowano jako wspólną rodzinę peptydów podobnych do FMRF-amidu (Phe-Met-Arg-Phe). Obecnie jednak tworza one odrębne rodziny neuropeptydów, $z$ powodu braku pokrewieństwa przejawiającego się w kodowaniu ich prekursorów przez odrębne geny oraz $\mathrm{w}$ wiązaniu $\mathrm{z}$ odrębnymi receptorami (COAST i SCHOOLEY 2010, NÄSSEL i WEGENER 2011). 


\section{STRATEGIE STOSOWANE W BADANIACH NEUROPEPTYDOMU OWADZIEGO}

Mimo iż historia badań nad peptydami sięga poczatku XX w., metody pozwalajace na ich wydajna ekstrakcję $i$ analizę opracowano stosunkowo niedawno. Nowoczesna aparatura, która stanowi zaplecze techniczne neuropeptydomiki, pozwala pokonać większość trudności związanych $z$ identyfikacja i badaniem roli neuropeptydów zwierząt zarówno kręgowych, jak i bezkręgowych (SCHRADER i współaut. 2014). W przypadku bezkręgowców kluczowe znaczenie ma umiejętność oczyszczenia, a następnie praca $z$ niewielka ilościa analitu, który stanowia badane neuropeptydy wyekstrahowane uprzednio $\mathrm{z}$ określonych struktur układu neuroendokrynowego.

W badaniach nad identyfikacja neuropeptydów wyróżnić można dwie zasadnicze strategie dotyczace sposobu pozyskiwania i analizy materiału (Ryc. 2). Pierwsza $z$ nich opiera sie na przygotowaniu ekstraktu z wypreparowanej struktury układu neuroendokrynowego, frakcjonowaniu otrzymanego ekstraktu, a następnie identyfikacji neuropeptydów w poszczególnych frakcjach z wykorzystaniem spektrometrii mas (CLYNEN i współaut. 2003). W przeciwieństwie do badań proteomicznych, gdzie identyfikowane białka poddaje się wstępnemu trawieniu przy udziale trypsyny lub innych enzymów proteolitycznych, analiza peptydów nie uwzględnia etapu trawienia $z$ udziałem peptydaz. Dzięki temu możliwa jest identyfikacja natywnej sekwencji aminokwasowej neuropeptydów wraz ze wszystkimi modyfikacjami potranslacyjnymi (FRICKER i współaut. 2006). Następująca po śmierci organizmu proteoliza niewielkiej ilości danego białka nie stanowi problemu w identyfikacji zachowanej części, natomiast degradacja peptydu występujacego $\mathrm{w}$ znacznie niższych stężeniach, może w sposób istotny wpłynąc na wynik analizy (Clynen i współaut. 2003). Bardzo często mniejsze frakcje będące wynikiem fragmentacji danego białka, wykazuja silniejszy sygnał niż obecne w tym samym ekstrakcie peptydy. Problem ten można zniwelować izolujac tkanki charakteryzujące się wysoka zawartościa peptydów przy jednocześnie niskim poziomie enzymów degradujących (DESIDERIO 1999, CHE i FRICKER 2005). Innym rozwiazaniem jest zastosowanie kolumny powinowactwa $\mathrm{w}$ celu oddzielenia peptydów od produktów pośrednich degradacji białek. Alternatywny sposób stanowi ekstrakcja peptydów połączona $z$ natychmiastowa inaktywacja proteaz odpowiedzialnych za generowanie fragmentów białka, utrudniajacych interpretację wyników. Ponadto, obecność grupy amidowej na $C$-końcu wielu peptydów pozwala natychmiast odróżnić je od pofragmentowanych sekwencji białek, które nie wykazuja tego rodzaju modyfikacji (FRICKER i współaut. 2006). Do rozdziału składników badanej próbki (ekstraktu) najczęściej stosuje się wysokosprawna chromatografię cieczowa i elektroforeze kapilarna (HORGAN i KENNY 2011). W neuropeptydomice do separacji neuropeptydów (1-10 kDa) nie wykorzystuje się natomiast elektroforezy dwuwymiarowej, która bardzo dobrze sprawdza się w rozdziale białek o masie $10-200 \mathrm{kDa}$ i punkcie izoelektrycznym pomiędzy 4 a 10 . Klasyczna

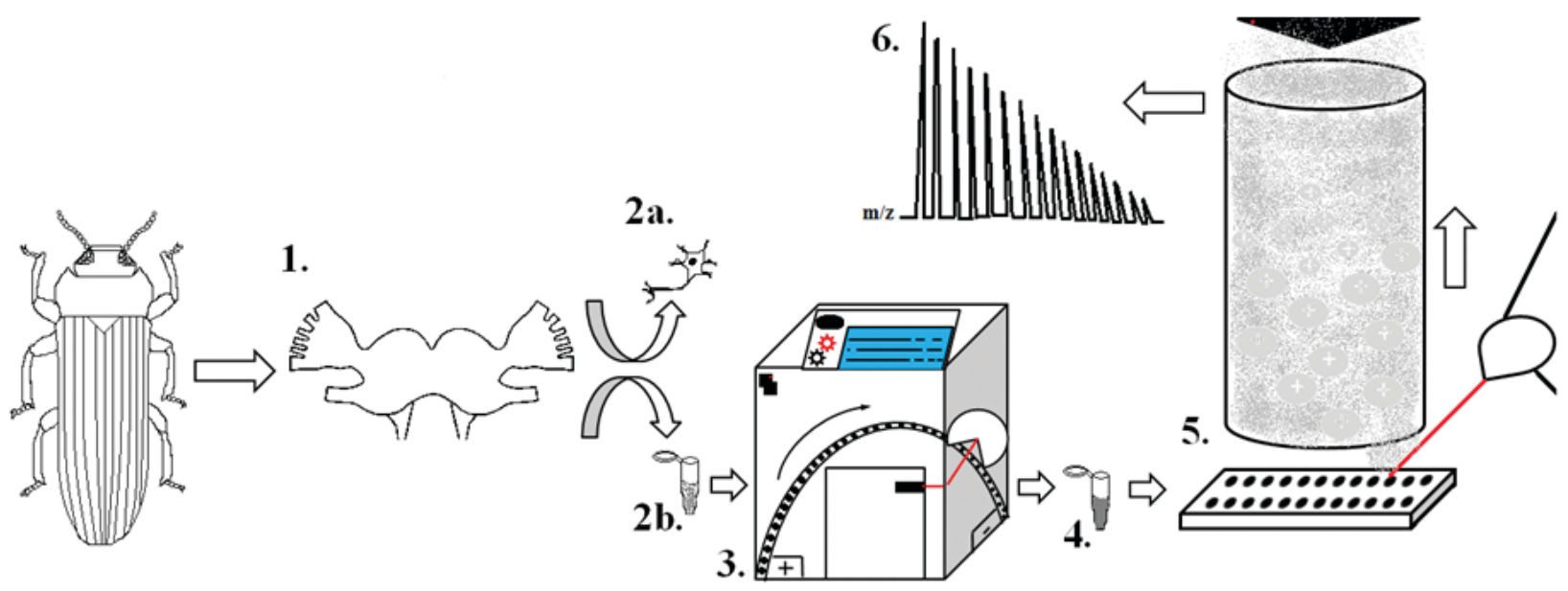

Ryc. 2. Strategie stosowane w neuropeptydomice do identyfikacji neuropeptydów:

Izolacja tkanki (1), Izolacja pojedynczej komórki (2a), Przygotowanie ekstraktu/roztworu ekstrakcyjnego (2b), Frakcjonowanie otrzymanego ekstraktu metoda elektroforezy kapilarnej (3), Pobranie frakcji zawierajacej neuropeptydy (4), Naniesienie pojedynczej komórki lub fragmentu ekstraktu na matrycę spektrometru masowego (5), Analiza widma masowego (6). 


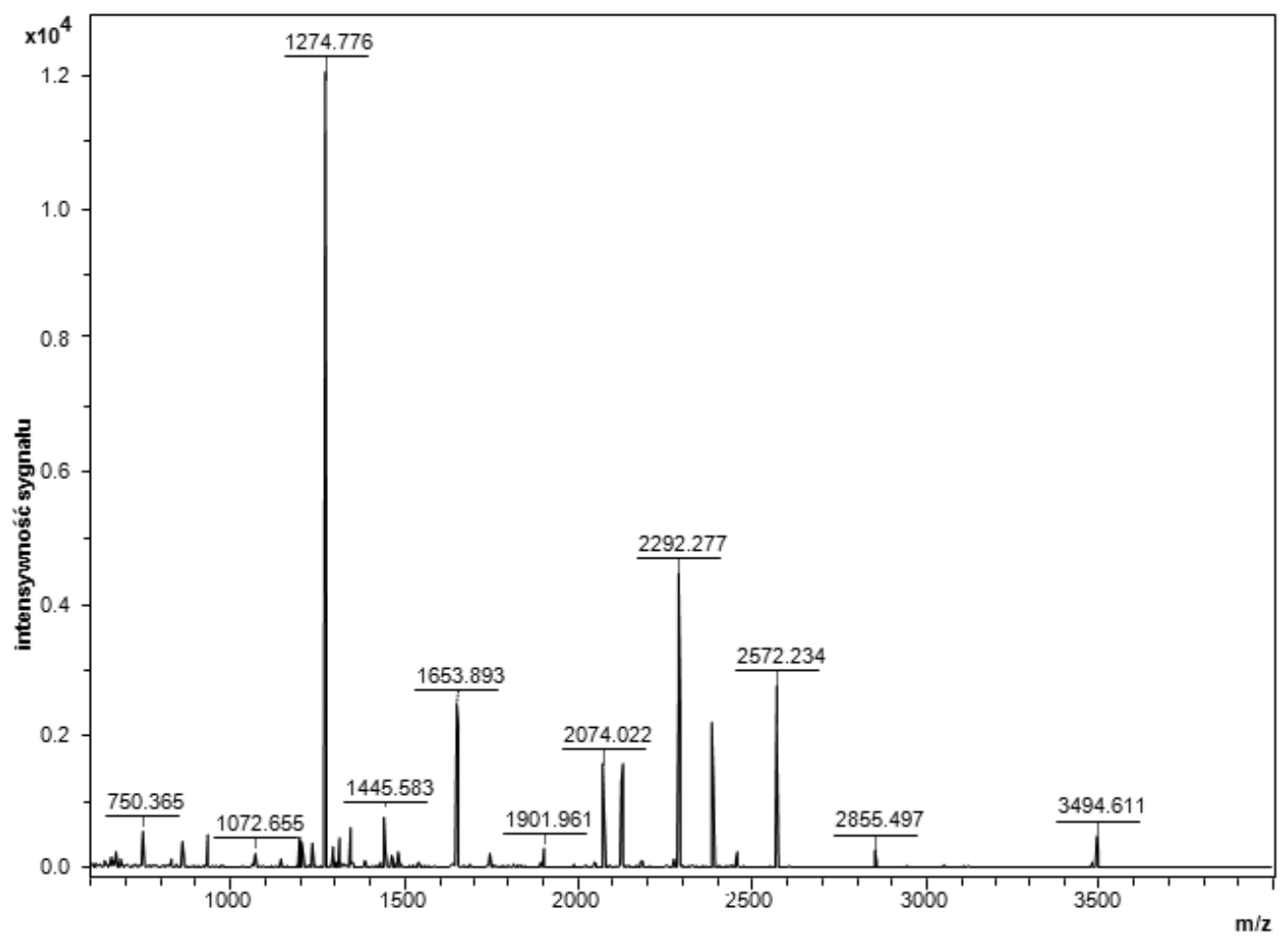

Ryc. 3. Spektrum masowe (MALDI-TOF) otrzymane przez bezpośrednie profilowanie tkanki (peptydowy odcisk palca) odwłokowego nerwu segmentalnego chrzasszcza Zophobas atratus.

Ustawienia zoptymalizowano dla peptydów o niższym zakresie stosunku m/z: 600-3500.

procedura oczyszczania i rozdziału peptydów polegała na seryjnym poddaniu homogenatu chromatografii cieczowej. Rozdzielone peptydy poddawane sa następnie procedurze sekwencjonowania. Początkowo sekwencje aminokwasowe peptydów ustalano metoda degradacji Edmana, polegajaca na sukcesywnym odłączaniu oznakowanych aminokwasów z $N$-końca cząsteczki peptydu. Procedura ta jest jednak bardzo czasochłonna i wymaga dużej ilości materiału biologicznego (Clynen i współaut. 2003). Z tego względu pierwsza izolacja owadziego neuropeptydu, proktoliny, wymagała wykorzystania 125.000 karaczanów Periplaneta americana (STARRAT i BROwN 1975). Obecnie dzięki wprowadzeniu bardziej precyzyjnych technik, wiarygodne wyniki uzyskuje się ograniczając jednocześnie liczbę osobników badanego gatunku modelowego.

Druga strategia zakłada analizę neuropeptydów bezpośrednio w tkankach bez wcześniejszej ekstrakcji (Ryc. 2). Połączenie metody polegajacej na znakowaniu komórek i techniki MS, umożliwia charakterystykę neuropeptydomu na poziomie pojedynczych neuronów. Dzięki tej metodzie możliwa jest identyfikacja składu neuropeptydów w obrębie całych gruczołów, np. CC, CA lub PG (NEUPERT i PREDEL 2005). Uzyskane $\mathrm{w}$ ten sposób widmo masowe określa- ne jest mianem peptydowego odcisku palca (ang. peptide fingerprint) tkanki/komórki (Ryc. 3). Ograniczenie analizy do konkretnych komórek, typów komórek neurosekrecyjnych oraz tkanek gruczołowych pozwala określić ich funkcje na tle pozostałych składowych układu neuroendokrynowego. Stanowi to punkt wyjścia dla dalszych badań nad rola neuropeptydów syntetyzowanych w komórkach wyznakowanych immunocytochemicznie (FRICKER i współaut. 2006). Zastosowanie takiej strategii dało możliwość identyfikacji w ostatniej dekadzie ponad 450 neuropeptydów bezkręgowców oraz otworzyło nowe perspektywy efektywnej analizy neuropeptydomów kolejnych gatunków owadów. Początkowo określanie profilu neuropeptydowego pojedynczych komórek stosowano w odniesieniu do organizmów kręgowych (Hummon i współaut. 2006). Z czasem, skład neuropeptydów zaczęto analizować również w pojedynczych neuronach bezkręgowców. Pierwsze opublikowane wyniki dotyczyły badań przeprowadzonych na mięczakach morskich i słodkowodnych, takich jak odpowiednio Aplysia californica i Lymnea stagnalis. Ze względu na stosunkowo dużą wielkość neuronów oraz względnie nieskomplikowana budowę układu nerwowego, organizmy te stanowia dogodny model do badań w zakresie neuropeptydomiki (CLYNEN 
i współaut. 2003). Analizę neuropeptydomu dla zidentyfikowanych pojedynczych neuronów owada po raz pierwszy przeprowadzono w oparciu o MS i znakowanie dekstranem tetrametylorodaminy. U karaczana $P$. americana $\mathrm{w}$ każdej $\mathrm{z}$ ośmiu analizowanych tylnobocznych komórek nerwowych zwoju metatorakalnego uzyskano wysoce powtarzalne widma masowe dwudziestu jeden neuropeptydów $z$ rodziny peptydów podobnych do FMRF-amidu (NEUPERT i PREDEL 2005). Współczesne podejście neuropeptydomiki nie ogranicza się do badań profilu peptydowego pojedynczych komórek, ale koncentruje się również na analizie składu struktur subkomórkowych. Ocena zawartości pęcherzyków o dużej gęstości, w których transportowane sa neuropeptydy, pozwala na uzyskanie informacji dotyczacych biosyntezy, załadunku i przemian tych związków. W obrębie jednego pęcherzyka wykryć można kilka produktów odrębnych genów, ulegających koekspresji w określonym stanie fizjologicznym organizmu. Pęcherzyki o średnicy $1 \mu \mathrm{m}$, to jak dotad najmniejsze próbki biologiczne profilowane z wykorzystaniem MS (CLYNEN i współaut. 2003). Badanie organelli odgrywajacych rolę w szlakach wydzielniczych poszerza wiedze na temat sygnalizacji wewnatrz- i międzykomórkowej, w której uczestniczą neuropeptydy (PREDEL 2001).

Inne podejście metodologiczne, polegające na obrazowaniu różnic $\mathrm{w}$ profilu neuropeptydowym hemolimfy owadów kontrolnych i poddanych działaniu określonego czynnika, daje możliwość oceny zmian ekspresji genów dla neuropeptydów zaangażowanych w odpowiedź fizjologiczna. Przykładem takiej analizy może być badanie profilu neuropeptydów odpowiadajacych za reakcje immunologiczne w hemolimfie $D$. melanogaster, indukowanych stymulacja układu odpornościowego poprzez wprowadzenie komórek bakteryjnych Staphylococcus aureus (CLYNEN i współaut. 2003). Udoskonalenie obecnych strategii badawczych pozwoli zwiększyć dynamikę badań neuropeptydomów owadów i znacznie ułatwi analizę na ograniczonych ilościach materiału biologicznego. Najnowsze strategie identyfikacji i opisu neuropeptydomów nie tylko owadów, ale także innych bezkręgowców, zakładaja analizę MS w oparciu o badanie transkryptomów komórek/gruczołów neuroendokrynowych. Pozwala to na dokładne określenie wszystkich neuropeptydów syntetyzowanych $\mathrm{u}$ badanego gatunku $\mathrm{w}$ danym stanie fizjologicznym. Neuropeptydomika nie jest więc gałęzia nauki odseparowana od pozostałych dziedzin, ale ich integralna częścia, wykorzystujaca dane $z$ analiz genomiki i transkryptomiki (ONS i współaut. 2016, ZATYLNY-GAUDIN i współaut. 2016). Zidenty- fikowane sekwencje aminokwasowe neuropeptydów podlegaja następnie archiwizacji w bazach danych tworząc biblioteki neuropeptydowe (AlTSTEIN i NÄSSEL 2010). Oprócz wykrywania neuropeptydów wraz $z$ ich modyfikacjami potranslacyjnymi, dąży się także do identyfikacji sekwencji receptorów, z którymi łącza się wykryte neuropeptydy (LEE 2016).

\section{SPEKTROMETRIA MAS W NEUROPEPTYDOMICE OWADÓW}

Istota MS jest wykonanie widma masowego w pełnym zakresie stosunku masy do ładunku elektrycznego $(\mathrm{m} / \mathrm{z})$ obojętnych pierwotnie czasteczek, połączone najczęściej $z$ fragmentacją jonów macierzystych. Bardzo wysoka czułość tej techniki sprawia, że stanowi ona optymalne narzędzie do analizy wysoce złożonych związków i ich mieszanin. Ocena wyników dokonywana jest na podstawie interpretacji uzyskanego finalnie widma masowego (HoRGAN i KENNY 2011). Pomimo różnic w konstrukcji poszczególnych spektrometrów mas, jak i stosowanych procedurach zależnych m.in. od rodzaju analizowanych czasteczek (białek, peptydów lub metabolitów), w każdym spektrometrze wyróżnić można stałe elementy budowy. Należą do nich: układ wprowadzania próbki, generator jonów, analizator $m / z$, detektor, rejestrator i analizator danych (Ryc. 4).

Pierwszym etapem procedury badawczej jest jonizacja badanej próbki, która umożliwia następnie odchylenie strumienia uzyskanych jonów w polu elektrycznym. Panujaca wewnątrz układu próżnia, dzięki której w ruch obdarzonych ładunkiem czasteczek nie ingerują gazy, uzależnia trajektorię wiazki jonów wyłącznie od oddziaływania $z$ polem elektrycznym. Uformowana wiazka kierowana jest następnie do analizatora mas, gdzie

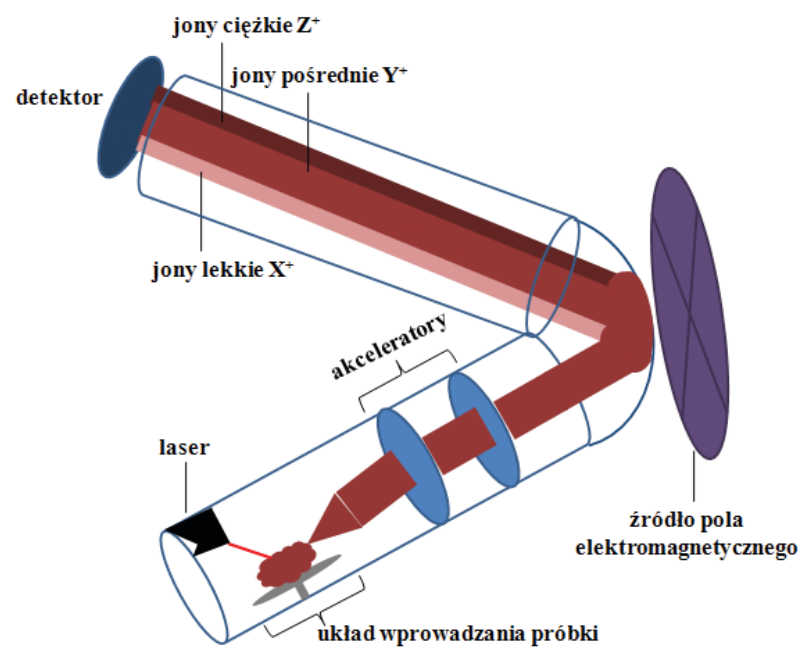

Ryc. 4. Ogólna budowa spektrometru mas. 
następuje rozdzielenie jonów według stosun$\mathrm{ku}$ ich masy do ładunku. Sygnał pradu jonowego jest ostatecznie przekształcany przy udziale detektora w sygnał elektryczny, rejestrowany i wizualizowany $\mathrm{w}$ postaci widma masowego. Obrazuje ono częstość wykrywania przez detektor jonów o określonym stosunku masy do ładunku (HEBDA 2009).

O zaawansowaniu technologicznym spektrometrii mas świadczy m.in. różnorodność technik jonizacji oraz analizy badanych związków. Wyróżnia się dwie podstawowe metody jonizacji cząsteczek: "miękka” i „twarda”. Do jonizacji biomolekuł, takich jak neuropeptydy, stosuje się metodę miękka, podczas której tworzy się jedynie jon molekularny (cząsteczkowy). Z kolei podczas jonizacji twardej, czasteczka np. kwasu organicznego rozpada się na mniejsze fragmenty tzw. jony potomne (PORTOLES i współaut. 2011). Wśród nowoczesnych metod generowania jonów najczęściej stosowana w neuropeptydomice jest desorpcja laserowa $Z$ udziałem matrycy (ang. matrix assisted laser desorption and ionisation, MALDI) oraz elektrorozpylanie (ang. electrospray ionisation, ESI). MALDI zaliczana jest do łagodnych metod jonizacji, podczas której nie dochodzi do fragmentacji cząsteczek (PŁODZICH 2013). Matryca posiadajacca zdolność do absorpcji energii wiazki lasera, przekazuje ja następnie badanej substancji. Pośrednictwo matry- cy w transmisji energii, zabezpiecza próbkę przed rozkładem. $Z$ kolei istota ESI jest doprowadzenie do jonizatora badanej substancji w mieszaninie wody i lotnego zwiazku, celem przeprowadzenia jej w stan aerozolu. Kolejny etap polega na odparowaniu rozpuszczalnika $Z$ mikroskopijnych kropel w komorze próżniowej do momentu, w którym $z$ wyjściowej kropli pozostanie wyłacznie analizowana cząsteczka. Mimo iż procedura ESI, podobnie jak MALDI, nie doprowadza do rozpadu peptydów, zapewnia większa precyzyjność ze względu na możliwość obdarzenia analizowanych cząsteczek więcej niż trzema ładunkami. Umożliwia to uzyskanie sygnału przy istotnie mniejszych wartościach $\mathrm{m} / \mathrm{z}$, pozwalajacc na zastosowanie analizatora o niższym spektrum mas $i$ wygenerowanie odpowiedniego widma masowego (MEULEMAN i współaut. 2008, BANERJEE i MAZUMDAR 2012).

Do alternatywnych metod warunkujacych powstawanie jonów w MS należą również termorozpylanie (ang. termospray, TE), jonizacja chemiczna (ang. chemical ionisation, CI), bombardowanie szybkimi atomami (ang. fast-atom bombardment, FAB), bombardowanie jonami (ang. secondary ion mass spectrometry, SIMS), klasyczna desorpcja laserowa (ang. laser desorption, LD), jonizacja chemiczna pod ciśnieniem atmosferycznym (ang. atmospheric pressure chemical ionisa-

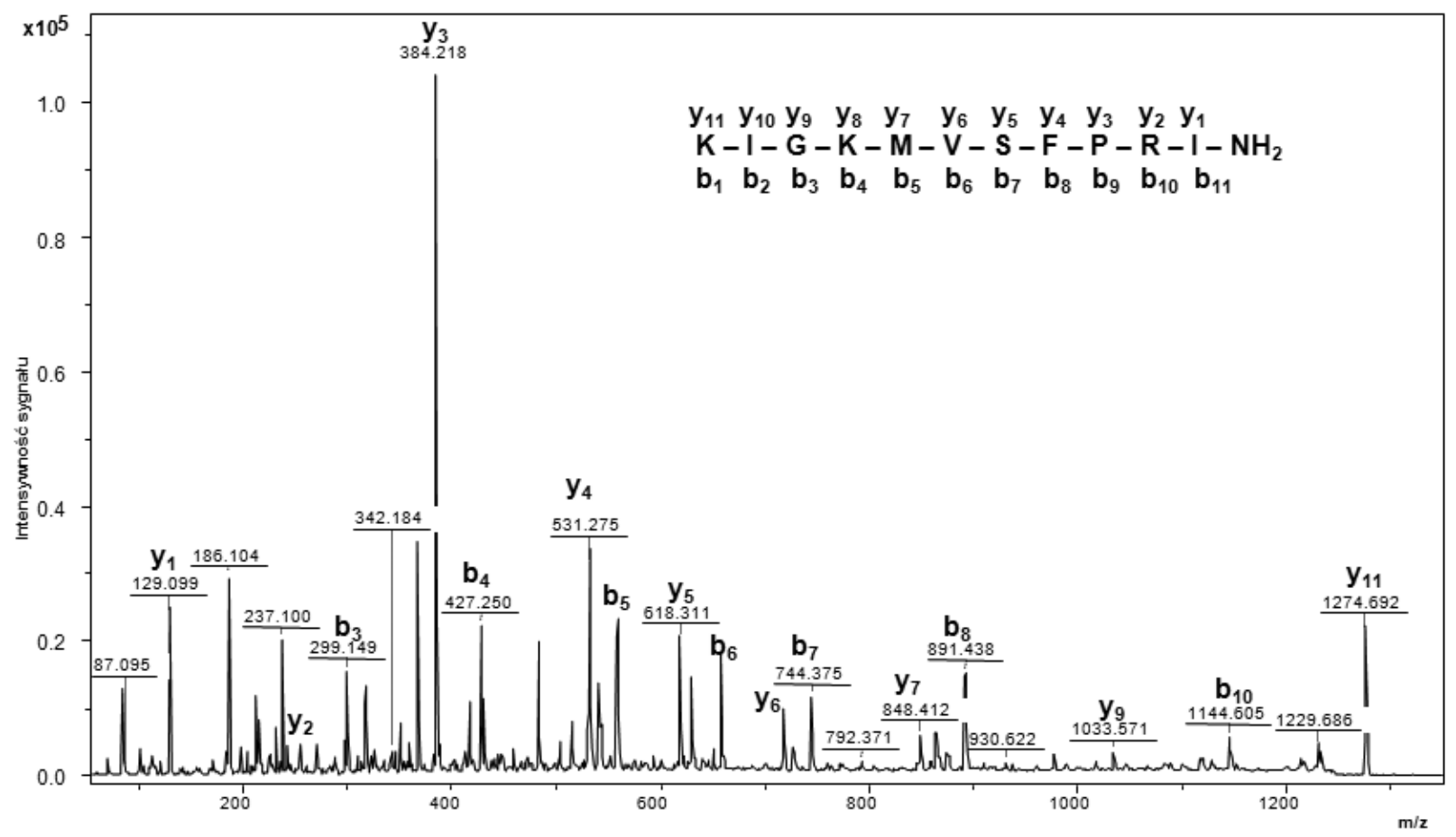

Ryc. 5. Spektrum fragmentacyjne jonu o stosunku $\mathrm{m} / \mathrm{z} 1274,7$.

Oznaczono jony fragmentacyjne pozwalające na określenie sekwencji aminokwasowej KIGKMVSFPRIa charakterystycznej dla peptydu Zopat-PVK-2 (peptydy z rodziny CAPA) występującego u chrząszcza Zophobas atratus. 
tion, APCI), jonizacja w plazmie wzbudzonej indukcyjnie (ang. inductively coupled plasma, ICP) oraz jonizacja elektronami (ang. electron ionisation, EI). APCI, ICP oraz EI jako metody jonizacji twardej nie sa wykorzystywane do identyfikacji biomolekul, takich jak peptydy, które nie powinny ulegać fragmentacji podczas analizy. Ponadto, ICP i EI nie nadaja się do analizy związków nietrwałych termicznie (HORGAN i KENNY 2011).

Różnorodności technik jonizacji odpowiada szeroki wachlarz sposobów analizy, określony przez budowę analizatorów. Do najczęściej wykorzystywanych należy analizator czasu przelotu (ang. time of flight, TOF) stosowany równolegle $z$ jonizatorem MALDI. Zasada działania TOF polega na pomiarze czasu uzależnionym od $\mathrm{m} / \mathrm{z}$ dla translokacji jonów $\mathrm{z}$ jonizatora do detektora.

Identyfikacje konkretnych sekwencji aminokwasowych umożliwia tandemowa spektrometria mas (ang. mass spectrometry/ mass spectrometry, MS/MS), będaca wynikiem połączenia dwóch analizatorów TOF. W tym przypadku jony pierwotne po wstępnej analizie fragmentowane sa do postaci jonów potomnych, których czas przelotu mierzony jest przez drugi analizator (GoGichAEVA i współaut. 2007). Do fragmentacji dochodzi na skutek przerywania wiązań peptydowych, indukowanego zderzeniami czasteczek (Ryc. 5). Fragmentacja białek zachodzi w następstwie indukcji zderzeniowej (ang. collision-induced dissociation, CID), indukcji rozpadu $z$ wychwytem elektronów (ang. electron-capture dissociation, ECD) lub rozpadu $z$ transportem elektronów (ang. electron-transfer dissociation, ETD) (ELVIRI 2012). Inny rodzaj równie popularnego analizatora stanowi analizator kwadrupolowy (ang. quadrupole, QP). Tworza go cztery symetrycznie rozmieszczone równoległe pręty, przepuszczające jony o konkretnej wartości $\mathrm{m} / \mathrm{z}$. Do prętów tworzacych kwadrupol przykładany jest prad zmienny o ustalonym napięciu oraz częstotliwości. Spektrum jonów filtrowanych na podstawie masy można zminimalizować lub zmaksymalizować regulujacc napięcie prądu lub liczbę kwadrupoli. Analizator ten stosowany jest najczęściej w spektrometrach wyposażonych $\mathrm{w}$ jonizator ESI (BANERJEE i MAZUMDAR 2012). Alternatywną możliwością bardzo czułego analizatora o podobnej zasadzie działania jest pułapka jonowa (ang. ion trap, IT). W zależności od parametrów prądu przyłożonego do elektrod, w pułapce jonowej można uwięzić jony o określonej wartości $\mathrm{m} / \mathrm{z}$. Znajdujące się wewnattrz pułapki atomy helu pod ciśnieniem, zderzajac się $z$ jonami spowalniaja ich ruch, utrudniajac tym samym ucieczke $\mathrm{z}$ pułapki. Dodatkowo jony w stanie wzbudzonym moga ulegać fragmentacji w wyniku zderzeń $\mathrm{z}$ atomami helu (Xu i współaut. 2009). Do równie popularnych analizatorów $\mathrm{m} / \mathrm{z}$ należą: sektor magnetyczny (ang. magnetic sector, $\mathrm{SM}$ ), sektor elektryczny (ang. electric sector, SE), liniowa pułapka jonowa (ang. linear trap quadrupole, LTQ), analizator cyklotronowego rezonansu jonów (ang. ion cyclotron resonance, ICR), analizator cyklotronowego rezonansu jonów $z$ fourierowską transformacja wyników (ang. fourier transform ion cyclotron resonance, FT-ICR), oraz orbitrap (orbitrap, OT). FT-ICR $\mathrm{w}$ przeciwieństwie do innych analizatorów nie niszczy wygenerowanych jonów, dzięki czemu moga być one poddane dalszej analizie $\mathrm{w}$ innych warunkach (HORGAN i KeNNY 2011). Uzyskane na podstawie analizy widm masowych wyniki, po wprowadzeniu do specjalistycznego oprogramowania, porównywane sa następnie $z$ sekwencjami znanych neuropeptydów. Przeszukiwanie baz danych odbywa się najczęściej $z$ zastosowaniem wyszukiwarek typu Mascot, SEQUEST, X! Tandem, Peaks Studio czy ProSight PC (LEE 2016). Różnorodność jonizatorów, analizatorów i detektorów jonów zestawianych w sposób umożliwiający optymalne wykorzystanie ich potencjału, wraz z zaawansowanymi metodami rozdziału mieszanin, a także rosnacymi zasobami danych i możliwościami obliczeniowymi komputerów umożliwia precyzyjna identyfikacje neuropeptydów bez konieczności predykcji ich sekwencji aminokwasowej a priori. Sytuuje to spektrometrie mas na czele stosowanych obecnie technik neuropeptydomiki.

\section{OWADY O ZNANYM NEUROPEPTYDOMIE}

Identyfikacja składowych neuropeptydomu zwierzęcych modeli badawczych pozwala śledzić występowanie rodzin neuropeptydowych w obrębie poszczególnych typów zwierząt (ZHANG i współaut. 2014). Rozwój technik rozdziału i detekcji neuropeptydów umożliwia obecnie identyfikacje tego rodzaju neuromolekuł u owadów, niwelując dotychczasowe ograniczenia wynikające $z$ niewielkich rozmiarów większości gatunków. Do najlepiej poznanych rodzin neuropeptydów owadów należą: pirokininy, miosupresyny, sulfakininy, tachykininy, peptydy adypokinetyczne, neuropeptydy $\mathrm{F}$, krótkie neuropeptydy $\mathrm{F}$, allatotropiny $\mathrm{i}$ allatostatyny, a także peptydy regulujące rozwój i linienie (MARCINIAK i współaut. 2011, SŁOCIŃSKA i współaut. 2015). Neuropeptydy będące przedstawicielami tych rodzin identyfikowane sa najczęściej podczas analizy neuropeptydomu owadów. Prowadzone dotychczas badania $\mathrm{w}$ zakresie neu- 
Tabela 1. Owady o znanym neuropeptydomie.

\begin{tabular}{|c|c|c|}
\hline Gatunek & $\begin{array}{l}\text { Liczba zidentyfikowanych } \\
\text { neuropeptydów }\end{array}$ & Źródło \\
\hline Aedes aegypti & 75 & PREDEL i współaut. 2010 \\
\hline Anopheles gambiae & 45 & RIEHLE i współaut. 2002 \\
\hline Apis mellifera & 158 & HAN i współaut. 2015 \\
\hline Bombyx mori & 45 & ROLLER i współaut. 2008 \\
\hline Calliphora vomitoria & 31 & NeuroPep \\
\hline Camponotus floridanus & 39 & Schмітт i współaut. 2015 \\
\hline Chilo suppressalis & 51 & XU i współaut. 2016 \\
\hline Delia radicum & 40 & ZOEPHEL i współaut. 2012 \\
\hline Diploptera punctata & 22 & NeuroPep \\
\hline Drosophila melanogaster & 42 & YEW i współaut. 2009 \\
\hline Galleria mellonella & 14 & NeuroPep \\
\hline Glossina morsitans & 51 & CAERS i współaut. 2015 \\
\hline Gryllus bimaculatus & 12 & NeuroPep \\
\hline Helicoverpa armigera & 10 & NeuroPep \\
\hline Helicoverpa zea & 12 & NeuroPep \\
\hline Heliothis virescens & 50 & BERG i współaut. 2007 \\
\hline Leptinotarsa decemlineata & 12 & NeuroPep \\
\hline Locusta migratoria & 52 & Clynen i Schoofs 2009 \\
\hline Lucilia cuprina & 45 & RAHMAN i współaut. 2013 \\
\hline Manduca sexta & 34 & NeuroPep \\
\hline Mastotermes darwiniensis & 163 & Christie 2015 \\
\hline Musca domestica & 17 & NeuroPep \\
\hline Nasonia vitripennis & 51 & HAUSER i współaut. 2010 \\
\hline Neobellieria bullata & 18 & VERLEYEN i współaut. 2004 \\
\hline Periplaneta americana & 59 & NeuroPep \\
\hline Rhodnius prolixus & 42 & ONS i współaut. 2009 \\
\hline Schistocerca gregaria & 44 & Clynen i schoofs 2009 \\
\hline Tribolium castaneum & 80 & LI i współaut. 2008 \\
\hline
\end{tabular}

ropeptydomiki pozwoliły zdefiniować liczbę neuropeptydów tworzacych neuropeptydomy określonych gatunków owadów. W ostatnim dziesięcioleciu nastapił znaczny wzrost liczby publikacji dotyczacych badań nad neuropeptydomem, które stanowią jednak niewielki odsetek artykułów publikowanych na temat analiz proteomicznych (SCHRADER i współaut. 2014). Co więcej, wśród publikacji z zakresu neuropeptydomiki tylko niewielka część dotyczy owadzich modeli badawczych. Z dostępnych źródeł informacji jakim sa bazy danych, można uzyskać szybko ocenę stanu wiedzy na temat liczby i typu neuropeptydów zidentyfikowanych u danego gatunku owada (Tabela 1). Przykładem jest stosunkowo nowa baza NeuroPep, przy pomocy której określić można liczbę, nazwy, sekwencje aminokwasowe oraz przy- należność neuropeptydów do konkretnej rodziny. Jednak, podobnie jak w przypadku publikacji naukowych, przeszukiwanie baz danych również wskazuje na deficyt informacji dotyczacych składu neuropeptydowego u przedstawicieli poszczególnych rodzajów owadów. Ze względu na ogromna liczbę oraz istotny wpływ wielu gatunków na środowisko i życie człowieka, coraz więcej uwagi koncentruje się na poznaniu mechanizmów regulujących procesy fizjologiczne wliczajac czasteczki regulatorowe. Przykład tego rodzaju działań stanowi długoterminowy "Manhattan Project of Entomology", określany również jako „i5k”. Celem badań prowadzonych w ramach tego projektu jest zsekwencjonowanie przez zespoły na całym świecie genomów 5000 gatunków stawonogów, w tym owadów o priorytetowym zna- 
Tabela 2. Neuropeptydy owadów wykazujące homologię do hormonów kręgowców (wg TAGHERT i VEENSTRA 2003, FónAgy 2006, HARTEnstein 2006, VAudry i współaut. 2009, COAST i SchOOley 2010, MARCINIAK i współaut. 2011, REYNOLDS 2013).

\begin{tabular}{|c|c|c|}
\hline Neuropeptyd owadzi & Homolog kręgowców & Funkcja \\
\hline Allatostatyny & Statyny/Somastatyna/Galanina & $\begin{array}{l}\text { Inhibicja syntezy i wydzielania hormonów z cor- } \\
\text { pora allata/przedniego płata przysadki mózgo- } \\
\text { wej }\end{array}$ \\
\hline Allatotropiny & Liberyny/Somatotropina & $\begin{array}{l}\text { Stymulacja corpora allata/przedniego płata } \\
\text { przysadki mózgowej do biosyntezy i sekrecji } \\
\text { hormonów }\end{array}$ \\
\hline Hormony adypokinetyczne & Glukagon & $\begin{array}{l}\text { Uwalnianie substratów energetycznych do pły- } \\
\text { nów ustrojowych (hemolimfy/krwi) }\end{array}$ \\
\hline $\begin{array}{l}\text { Hormony adypokinetyczne/ko- } \\
\text { razonina }\end{array}$ & Gonadoliberyny & Regulacja wzrostu i rozwoju oraz rozmnażania \\
\hline $\begin{array}{l}\text { Neuropeptydy F i krótkie neu- } \\
\text { ropeptydy F }\end{array}$ & Neuropeptydy Y & $\begin{array}{l}\text { Regulacja procesów związanych z odżywianiem, } \\
\text { modulowanie aktywności kurczliwej mięśni } \\
\text { przewodu pokarmowego }\end{array}$ \\
\hline Peptyd insulinopodobny & Insulina & $\begin{array}{l}\text { Obniżanie poziomu substratów energetycznych } \\
\text { w płynach ustrojowych (hemolimfie/krwi) }\end{array}$ \\
\hline Inotocyna & Wazopresyna/Oksytocyna & $\begin{array}{l}\text { Regulacja procesów związanych z diureza, regu- } \\
\text { lacja skurczów mięśni }\end{array}$ \\
\hline $\begin{array}{l}\text { Peptydy diuretyczne podobne } \\
\text { do kortykoliberyny }\end{array}$ & Kortykoliberyna & $\begin{array}{l}\text { Zwiększenie funkcji sekrecyjnych przez cewki } \\
\text { Malpighiego, stymulacja uwalniania kortykotro- } \\
\text { piny }\end{array}$ \\
\hline Sulfakininy & Cholecystokinina & Hamowanie pobierania pokarmu \\
\hline Tachykinino-podobne peptydy & Substancja P & Stymulowanie kurczliwości mięśni gładkich jelit \\
\hline Peptydy CAPA & Neuromedyna U & Stymulacja skurczów mięśni trzewnych \\
\hline $\begin{array}{l}\text { Peptydy podobne do FMRFa- } \\
\text { midu }\end{array}$ & Peptydy $z$ rodziny RFamidu & Regulacja skurczów serca i mięśni trzewnych \\
\hline $\begin{array}{l}\text { Peptydy diuretyczne podobne } \\
\text { do kalcytoniny }\end{array}$ & Kalcytonina & Regulacja procesów osmotycznych \\
\hline
\end{tabular}

czeniu dla człowieka. Jak dotą do identyfikacji neuropeptydomu nominowano 703 gatunki owadów, w tym 256 z rzędu Hymenoptera oraz 63 gatunki stawonogów $z$ podtypu Chelicerata, 25 gatunków $z$ podtypu Crustacea i 6 gatunków $z$ podtypu Myriapoda (Evans i współaut. 2013). Realizacja projektu i5k pozwoli zidentyfikować geny kodujace m.in. neuropeptydy owadów.

Jak dotad najlepiej poznano neuropeptydomy owadów, które wykorzystywane sa jako organizmy modelowe w badaniach eksperymentalnych. Istotne jest również to, że znacznie więcej informacji uzyskać można na temat składu neuropeptydowego owadów o odpowiednio dużych rozmiarach, w przypadku których izolacja struktur układu neuroendokrynowego jest łatwiejsza. U większości owadów konstytutywny zestaw neuropeptydów odpowiedzialnych za regulację podstawowych procesów fizjologicznych jest bardzo podobny. Niemniej jednak, zi- dentyfikowane neuropeptydy mimo przynależności do jednej rodziny oraz pełnienia tej samej funkcji fizjologicznej, często wykazują różnice $\mathrm{w}$ sekwencji aminokwasowej w zależności od gatunku owada (CLYNEN i SCHOOFS 2009, NÄSSEL i WEGENER 2011). Ponadto, wiele owadów żyjacych w środowiskach o niesprzyjajacych warunkach posiada unikatowe neuropeptydy zapewniajace im odpowiednie przystosowanie na drodze adaptacji, warunkujace przetrwanie organizmu (DAVIES i współaut. 2014, TERHZAZ i współaut. 2015).

\section{ZNACZENIE BADAŃ NAD NEUROHORMONALNA REGULACJA PROCESÓW ŻYCIOWYCH U OWADÓW}

Udowodnienie $\mathrm{w}$ wielu biotestach kluczowej roli układu neuroendokrynowego w regulacji procesów fizjologicznych u owadów motywowało badaczy do identyfikacji 
i ustalania funkcji (bardzo często plejotropowej) wielu neuropeptydów, co ostatnio stanowi szczególnie szybko rozwijający się kierunek badań. Pierwsze prace nad regulacją procesów życiowych owadów przez neuropeptydy miały miejsce już na początku XX w. Główna strategia prowadzonych doświadczeń opierała się wtedy na usuwaniu poszczególnych struktur wydzielających hormony, a następnie obserwacji morfologii i behawioru oraz monitorowaniu fizjologii owada. Już w 1917 r. polski pionier neuroendokrynologii owadów, Stefan Kopeć, dowiódł, że przewiązka zagłowowa zaciśnięta między głowa a tułowiem gassienicy $L y$ mantria dispar uniemożliwia jej metamorfozę. Wykazał on tym samym, że mózg owada wydziela związki, które działaja nie tylko lokalnie, ale wywierają także wpływ na odległe narządy (KOPEĆ 1917, 1922). Mimo odkrycia endokrynowego działania hormonów peptydowych, nie podejrzewano wtedy jak duże podobieństwo w zakresie struktury i funkcji układu neuroendokrynowego łaczy owady i kręgowce. Analogie pomiędzy funkcjonowaniem układu retrocerebralnego owadów i układem podwzgórze-przysadka mózgowa kręgowców wykryto dopiero kilkanaście lat później (HARTENSTEIN 2006, DE Loof i współaut. 2012). Ponadto, wiele neuropeptydów owadzich posiada cechy funkcjonalne ich odpowiedników u kręgowców (Tabela 2). Niektóre $z$ nich wykazuja również podobieństwo strukturalne w zakresie sekwencji $C$-terminalnej oraz modyfikacji potranslacyjnych. Przykładowo, zidentyfikowane u owadów neuropeptydy tworzace rodzinę NPF uznane zostały za homologi neuropeptydów Y (ang. neuropeptides Y, NPY), które występują u kręgowców. W przypadku D. melanogaster i człowieka neuropeptydy te tworza 36-aminokwasowa sekwencję o wspólnym C-terminalnym motywie $\mathrm{RX}_{1} \mathrm{RX}_{2}$, gdzie dla $\mathrm{NPF} \mathrm{X}_{1}=\mathrm{V}$ a $\mathrm{X}_{2}=\mathrm{F}$, natomiast dla NPY $X_{1}=Q$ a $X_{2}=Y$ (NÄSSEL $i$ WEGENER 2011). Fenyloalaninę (F) i tyrozynę (Y) różni jedynie grupa hydroksylowa znajdujaca się w pozycji para niepolarnego pierścienia aromatycznego tyrozyny. W obu przypadkach aminokwas znajdujacy się na C-końcu jest zmodyfikowany przez przyłaczenie grupy amidowej, której obecność jest niezbędna dla aktywności fizjologicznej tych neuropeptydów (BOBIŃSKA i współaut. 2008). Polega ona przede wszystkim na regulacji procesów związanych $z$ odżywianiem (wzmaganie pobierania pokarmu), modyfikowaniu aktywności kurczliwej mięśni poszczególnych odcinków przewodu pokarmowego, kontroli rytmów okołodobowych i procesów związanych $z$ zapamiętywaniem, a także na modulacji reakcji lękowych (NÄSSEL i WE-
GENER 2011). Podobieństwo pomiędzy NPF i NPY sprawia, że wykorzystanie owadów jako organizmów modelowych do badań biomedycznych w zakresie neuroendokrynologii może dostarczyć wymiernych efektów w postaci nowych biotestów do analizowania mechanizmów związanych $z$ regulacja pobierania pokarmu u zwierzat. To tylko jeden $z$ wielu potwierdzonych przykładów strukturalno-funkcjonalnych analogii pomiędzy neurohormonalna koordynacja procesów życiowych u owadów i kręgowców. Sugeruje to wiele potencjalnych możliwości wykorzystania takich biotestów również do badania procesów rozwoju schorzeń związanych $z$ układem wydzielania wewnętrznego. Poznanie neuropeptydomu owadziego oraz roli poszczególnych jego komponentów może okazać się w przyszłości pomocne przy zaprojektowaniu antagonistów i agonistów receptorów ssaczych w celu ograniczenia zaburzeń wzrostu i rozwoju, lokomocji, reakcji na bodźce, gospodarki wodno-elektrolitowej, metabolizmu, procesów związanych $z$ reprodukcja oraz innych patologii o podłożu neuroendokrynowym (GRUBER 2014). Zainteresowanie badaczy funkcjami owadzich neuropeptydów nie ogranicza się jedynie do wykorzystania ich w przemyśle i poszukiwania nowych farmaceutyków. Poza tym doświadczenia przeprowadzone $z$ wykorzystaniem neuropeptydów regulujacych odżywianie u owadów oraz peptydów działających gonadoinhibicyjnie sugeruja możliwość opracowania specyficznych peptydomimetyków, które moga zostać wykorzystane jako bioinsektycydy (GÄDE i GOLDSWORTHY 2003, FóNAGY 2006). Stosowane obecnie środki fosforoorganiczne działające owadobójczo sa inhibitorami cholinoesteraz. Oddziałujac na płytki motoryczne wywołuja ostatecznie paraliż mięśni, przy czym ich działanie nie jest specyficzne tylko względem owadów. Ponadto, przedostając się do wód gruntowych powoduja poważne skażenie wody azotanami, fosforanami oraz związkami organicznymi działającymi toksycznie na rośliny i zwierzęta (RASTOGi i współaut. 2010). $Z$ tego względu pożądane jest rozwiazanie polegające na wykorzystaniu środków zawierających związki, które w sposób specyficzny reguluja procesy fizjologiczne owadów w celu ograniczenia ich żerowania oraz zdolności do reprodukcji. Największą zaleta tego rodzaju związków jest wybiórcze działanie, a także bardzo szybka biodegradacja w środowisku. Z kolei największą trudność stanowi opracowanie sposobu ich aplikacji do wnętrza ciała owada. Natura związków peptydowych uniemożliwia skuteczne podanie ich owadom droga pokarmowa ze względu na bezpośredni rozkład przy udzia- 
le enzymów trawiennych (ALTSTEIN i współaut. 2000). $Z$ tego powodu starania skoncentrowane sa także na sprzęganiu peptydów $z$ cząstkami pełniacymi rolę platformy nośnikowej, umożliwiającej penetrację kutikuli owada, lub $z$ substancjami zabezpieczającymi przed degradacja $z$ udziałem peptydaz. Jak dotąd udało się opracować pseudopeptydy wzbogacone o wielkogabarytowe przestrzennie struktury chemiczne, takie jak pierścień indanu, czy cyklopropylu przyłączone do aktywnego rdzenia cząsteczki, które zapewniaja oporność na enzymy peptydolityczne, przy zachowaniu aktywności biologicznej (NACHMAN i współaut. 1999). Tego rodzaju efekt zaobserwowano po polączeniu allatostatyny o $C$-końcowym motywie PISCF, wyizolowanej $z$ ćmy Manduca sexta (Manse-PISCF), z lektyna, pochodzaca $z$ cebulek przebiśniegu śnieżyczki Galanthus nivalis (FITCHES i współaut. 2002). Do związków, które podobnie jak allatostatyny hamuja żerowanie i selektywnie ograniczaja liczebność owadów należa peptydy gonadoinhibicyjne. W tym przypadku uwaga badaczy skoncentrowana jest przede wszystkim na czynnikach oostatycznych i modulujacych biosyntezę trypsyny (ang. trypsin modulating oostatic factor, TMOF) Aea-TMOF oraz Neb-TMOF w jecie odpowiednio komara Aedes aegypti i muchy Neobellieria bullata (BOROvsky $\mathrm{i}$ współaut. 2016). W tym samym celu wykorzystać można inne hormony peptydowe, takie jak Neb-kolostatynę czy neuroparsyny. Prowadzone dotychczas badania wykazały, że iniekcje tych hormonów hamują rozwój jajników, proces wzrostu i dojrzewania oocytów, zaburzaja syntezę i transport witellogenin oraz redukuja ilość składanych jaj u chrząszcza Tenebrio molitor. Ponadto dowiedziono, że iniekcje Neb-kolostatyny wywołuja u T. molitor zmiany w jajniku indukując atrezję pęcherzyków jajnikowych (WASILEWSKI i ROSIŃSKI 2007, CZARNIEWSKA i współaut. 2014). Wyniki badań nad neurohormonalna regulacja procesów życiowych u owadów $z$ pewnościa znajda $\mathrm{w}$ przyszłości zastosowanie praktyczne na szeroka skalę. Odkrywanie nowych właściwości endogennych peptydów u owadów może w znaczacy sposób poszerzyć zakres aplikacyjny badań prowadzonych $\mathrm{w}$ dziedzinie neuropeptydomiki oraz neuroendokrynologii bezkręgowców (ClaEYs i współaut. 2005, FÓNAGY 2006).

\section{Streszczenie}

Zasadniczą rolę w regulacji procesów fizjologicznych oraz utrzymaniu homeostazy u zdecydowanej większości organizmów zwierzęcych odgrywa układ neuroendokrynowy. Jak dotąd bardzo dobrze poznano funkcje neurohormonalnych mediatorów regulujacych procesy życiowe człowieka. W ostatniej dekadzie uwaga badaczy sku- pia się na identyfikacji i ocenie funkcji neuropeptydów owadzich oraz kodujących je genów. W niniejszej pracy scharakteryzowano budowę i funkcje układu neuroendokrynowego owadów, przedstawiono aktualny stan wiedzy dotyczacy trudności i strategii badań neuropeptydomu tych zwierząt ze szczególnym uwzględnieniem spektrometrii mas, a także obowiązujacej obecnie zasady klasyfikacji neuropeptydów. Ponadto opracowano wykaz gatunków owadów o znanym neuropeptydomie, określono funkcjonalne podobieństwa pomiędzy neuropeptydami owadów i ich homologami występującymi u kręgowców oraz zaprezentowano potencjalne możliwości aplikacyjne badań prowadzonych w zakresie neuropeptydomiki. Dostępne dane literaturowe wskazuja, że neuropeptydy zidentyfikowane dotychczas u modelowych gatunków owadów, takich jak Drosophila melanogaster moga posłużyć w przyszłości do projektowania nowych farmaceutyków oraz środków ograniczających liczebność owadów szkodliwych $z$ medycznego i gospodarczego punktu widzenia.

\section{LITERATURA}

Agui N., Granger N. A., Gilbert L. I., BollenBACHER W. E., 1979. Cellular localization of the insect prothoracicotropic hormone: In vitro assay of a single neurosecretory cell. Cell Biol. 76, 5694-5698.

AltSTEIN M., NÄSSEL D. R., 2010. Neuropeptide signaling in insects. Adv. Exp. Med. Biol. 692, 155-165.

Altstein M., Ben-AZIZ O., Schefler I., ZELTSER I., GILON CH., 2000. Advances in the application of neuropeptides in insect control. Crop Protect. $19,547-555$.

BANERJEE S., MAZUMDAR S., 2012. Electrospray ionisation mass spectrometry: a technique to access the information beyond the molecular weight of the analyte. Int. J. Anal. Chem., doi:10.1155/2012/282574.

BERG B. G., SCHACHTNER J., UtZ S., HOMBERG U., 2007. Distribution of neuropeptides in the primary olfactory center of the heliothine moth Heliothis virescens. Cell Tissue Res. 327, 385-398.

BOBIŃSKa K., SZEMRAJ J., PIETRAS T., ZBORALSKI K., GALECKI P., 2008. Neuropeptide Y - structure, receptors effect and its place in psychiatry. Psychiatria Polska 42, 889-901.

BOROVSKY D., STERNER A., POWELl C. A., 2016. Cloning and expressing trypsin modulating oostatic factor in Chlorella desiccata to control mosquito larvae. Arch. Insect Biochem. Physiol. 91, 17-36.

Caers J., Boonen K., Van Den AbBeele J., Van ROMPAY L., SchOOFS L., VAN HIEL M. B., 2015. Peptidomics of neuropeptidergic tissues of the tsetse fly Glossina morsitans morsitans. J. Am. Soc. Mass Spectr. 26, 2024-2038.

CARRow G. M., CAlabrese R. L., Williams C. M., 1981. Spontaneous and evoked release of prothoracicotropin from multiple neurohemal organs of the tobacco hornworm. Neurobiology 78, 5866-5870.

CHE F. Y., FRICKER L. D., 2005. Quantitative peptidomics of mouse pituitary: Comparison of different stable isotopic tags. J. Mass Spectr. 40, 238-249.

CHRISTIE A. E., 2015. In silico prediction of a neuropeptidome for the eusocial insect Mastotermes darwiniensis. Gen. Comp. Endocrinol. 224, 69-83.

Claeys I., Poels J., Simonet G., Franssens V., Van Loy T., Van Hiel M. B., Breugelmans B., 
VANDEN BROECK J., 2005. Insect neuropeptide and peptide hormone receptors: current knowl edge and future directions. Vitam. Horm. 73, 217-282.

Clynen E., Schoofs L., 2009. Peptidomic survey of the locust neuroendocrine system. Insect Biochem. Mol. Biol. 39, 491-507.

Clynen E., DE Loof A., Schoofs L., 2003. The use of peptidomics in endocrine research. Gen. Comp. Endocrinol. 132, 1-9.

Coast G. M., Schooley D. A., 2010, Toward a consensus nomenclature for insect neuropeptides and peptide hormones. Peptides 32, 620-631.

CZARniewska E., RosińsKi G., Gabata E., KUCZer M., 2014. The natural insect peptide Neb-colloostatin induces ovarian atresia and apoptosis in the mealworm Tenebrio molitor. BioMed Centr. Develop. Biol. 14, doi: 10.1186/1471213X-14-4.

DAHLIN A., 2005. Microscale tools for sample preparation, separation and detection of neuropeptides. Acta Universitatis Upsaliensis, Digital Comprehensive Summaries of Uppsala, Dissertations from the Faculty of Science and Technology, 64.

Davies S. A., Cabrero P., Overend G., Aitchison L., Sebastian S., Terhzaz S., Dow J. A T., 2014. Cell signalling mechanisms for insect stress tolerance. J. Exp. Biol. 217, 119-128.

De Loof A., Lindemans M., LiU F., DE GRoef B., SchoOfs L., 2012. Endocrine archeology: Do insects retain ancestrally inherited counterparts of the vertebrate releasing hormones GnRH, GHRH, TRH and CRF? Gen. Comp. Endocrinol. 177, 18-27.

DESIDERIO D. M., 1999. Mass spectrometric analysis of neuropeptidergic systems in the human pituitary and cerebrospinal fluid. J. Chromatogr. B Biomed. Sci. Appl. 731, 3-22.

Dillen S., Zels S., Verlinden H., SPIT J., VAN WiElENDAELE P., VANDEN BROECK J., 2013. Functional characterization of the short neuropeptide $F$ receptor in the desert locust, Schistocerca gregaria. PLoS One 8p, e53604.

ELVIRI L., 2012. ETD and ECD mass spectrometry fragmentation for the characterization of protein post translational modifications. Tandem Mass Spectrometry, Applications and Principles, www.intechopen.com, 161-178.

Ewer J., Gammie S. C., TRUman J. W., 1997. Control of insect ecdysis by a positive-feedback endocrine system: roles of eclosion hormone and ecdysis triggering hormone. J. Exp. Biol. 200, 869-881.

Evans J. J. D., BROWn S. J., ZHOU X., 2013. The $i 5 k$ initiative: advancing arthropod genomics for knowledge, human health, agriculture, and the environment. J. Hered. 104, 595-600.

FÄLTH M., SKÖLD K., SVENSSON M., NILSSON A., FENYÖ D., ANDREN P. E., 2007. Neuropeptidomics strategies for specific and sensitive identification of endogenous peptides. Mol. Cell. Proteom. 6, 1188-1197.

Fitches E., Audsley N., Gatehouse J. A., EDWARDS J. P., 2002. Fusion proteins containing neuropeptides as novel insect control agents: snowdrop lectin delivers fused allatostatin to insect haemolymph following oral ingestion. Insect Biochem. Mol. Biol. 32, 16531661.

FóNAGY A., 2006. Insect neuropeptides and their potential application for pest control. Acta Phytopathologica et Entomologica Hungarica 41, 137-152.
FRICKER L. D., LIM J., PAN H., CHE F. Y., 2006, Peptidomics: identification and quantification of endogenous peptides in neuroendocrine tissues. Mass Spectr. Rev. 25, 327-344.

GÄDE G., GOLDSWORTHY G. J., 2003. Insect peptide hormones: a selective review of their physiology and potential application for pest control. Pest Manage. Sci. 59, 1063-1075.

GÄDE G., HOFFMANN K. H., SPRING J. H., 1997. Hormonal regulation in insects: facts, gaps, and future directions. Physiol. Rev. 77, 9631032 .

Gogichaeva N. V., Williams T., Alterman M. A., 2007. MALDI TOF/TOF Tandem mass spectrometry as a new tool for amino acids analysis. J. Am. Soc. Mass Spectr. 18, 279-284.

GRUBER CH. W., 2014, Physiology of invertebrate oxytocin and vasopressin neuropeptides. Exp. Physiol. 99, 55-61.

HAIDER S., PAL R., 2013. Integrated analysis of transcriptomic and proteomic data. Curr. Genom. 14, 92-100.

HaN B., FANG Y., Feng M., Hu H., Qi Y., HuO X., Meng L., Wu B., LI J., 2015. Quantitative neuropeptidome analysis reveals neuropeptides are correlated with social behavior regulation of the honeybee workers. J. Prot. Res. 14, 4382-4393.

HARTENSTEIN V., 2006. The neuroendocrine system of invertebrates: a developmental and evolutionary perspective. J. Endocrinol. 190, 555570.

Hauser F., Neupert S., Williamson M., PRedel R., TANAKA Y., GRIMmelikHUiJZen C. J., 2010. Genomics and peptidomics of neuropeptides and protein hormones present in the parasitic wasp Nasonia vitripennis. J. Prot. Res. 9, 5296-5310.

HEBDA M., 2009. Computer program for thermal coupling analysis methods. Tech. Transact. 6, 45-51.

HORGAN R. P., KENNY L. C., 2011. SACreview 'Omic' technologies: genomics, transcriptomics, proteomics and metabolomics. Obstetric. Gynaecol. 13, 189-195.

Hummon A. B. Amare A., Sweedler J. V., 2006. Discovering new invertebrate neuropeptides using mass spectrometry. Mass Spectr. Rev. 25, 77-98.

KODRIK D., 2008. Adipokinetic hormone functions that are not associated with insect flight. Physiol. Entomol. 33, 171-180.

KOPEĆ S., 1917. Experiments on metamorphosis of insects. Bull. International de l'Academie des Sciences de Cracovie, 57-60.

KoPEĆ S., 1922. Studies on the necessity of the brain for the inception of insect metamorphosis. Biol. Bull. 42, 323-342.

LEE J. E., 2016. Neuropeptidomics: mass spectrometry-based identification and quantitation of neuropeptides. Genom. Inform. 14, 12-19.

LEGOCKI A. B., 2004. O nowa filozofie przyrody. Dyskurs miedzy redukcjonizmem a holizmem. Nauka 4, 99-104.

Li B., Predel R., Neupert S., Hauser F., TANAKa Y., Cazzamali G., Williamson M., ARaKane Y., Verleyen P., Schoofs L., Schachtner J., GRIMMELIKHUIJZEN C. J., PARK Y., 2008. Genomics, transcriptomics and peptidomics of neuropeptides and protein hormones in the red flour beetle Tribolium castaneum. Genom. Res. 18, 113-122.

MARCINIAK P., SZYMCZAK M., PACHOLSKA-BOGALSKA J., Aúdsley N., KUCZER M., Rosiński G., 2012. New myotropic and metabotropic ac- 
tions of pyrokinins in tenebrionid beetles. Gen. Comp. Endocrinol. 177, 263-269.

MARCINIAK P., SZYMCZAK M., ROSIŃSKI G., 2011. Hormony peptydowe owadów - przeglad najważniejszych rodzin. Post. Biol. Kom. 38, 4363.

Meuleman W., Engwegen J. Y. M. N., Gast M. CH. W., BEIJNEN J. H., Reinders M. J. T., Wessels L. F. A.. 2008, Comparison of normalisation methods for surface-enhanced laser desorption and ionisation (SELDI) time-of-flight (TOF) mass spectrometry data. BioMed Central Bioinform. 9, 1-11.

NACHMAN R. J., GARside CH. S., TOBE S. S., 1999. Hemolymph and tissue-bound peptidase-resistant analogs of the insect allatostatins. Peptides 20, 23-29.

NÄSSEL D. R., WEGENER CH., 2011. A comparative review of short and long neuropeptide $F$ signaling in invertebrates: Any similarities to vertebrate neuropeptide $Y$ signaling? Peptides 32, 1335-1355.

NEUPERT S., PREDEL R., 2005. Mass spectrometric analysis of single identified neurons of an insect. Biochem. Biophys. Res. Comm. 327, 640-645.

Ons S., Richter F., URlaub H., POMAR R. R., 2009. The neuropeptidome of Rhodnius prolixus brain. Proteomics 9, 788-792.

Ons S., Lavore A., Sterkel M., WulfF J. P., SiERRA I., MARTINEZ-BARNETCHE J., RODRIQUEZ M. H., RIVERA-POMAR R., 2016. Identification of $G$ protein coupled receptors for opsines and neurohormones in Rhodnius prolixus. Genomic and transcriptomic analysis. Insect Biochem. Mol. Biol. 69, 34-50.

PŁODZICH A., 2013. Proteomics and its application in selected diseases. J. Transf. Med. 6, 4859.

Portoles T., Pitarch E., Lopez F. J., Hernandez F., 2011. Use of soft and hard ionization tech niques for elucidation of unknown compounds by gas chromatography/time-of-flight mass spectrometry. Rapid Comm. Mass Spectr. 25 $1589-1599$

PREDEL R., 2001. Peptidergic neurohemal system of an insect: Mass spectrometric morphology. J. Comp. Neurol. 436, 363-375.

PREDEl R., NEUPERT S., GARCZYNSKI S. F., CRIM J. W., BRown M. R., Russell W. K., KaHNT J., Russell D. H., NACHMAN R. J., 2010. Neuropeptidomics of the mosquito Aedes aegypti. J. Proteom. Res. 9, doi:10.1021/pr901187p.

RAHMAN M. M., NEUPERT S., PREDEL R., 2013. Neuropeptidomics of the Australian sheep blowfly Lucilia cuprina (Wiedemann) and related Diptera. Peptides 41, 31-37.

RASTOGI S. K., TRIPATHI S., RAVISHANKER D., 2010. A study of neurologic symptoms on exposure to organophosphate pesticides in the children of agricultural workers. Indian J. Occup. Environ. Med. 14, 54-57.

REYNOLDS S., 2013. Neuroendocrine system. [W:] The insects structure and function. CHAPMAN R. F. (red.). Cambridge University Press, Cambridge, 674-708.

Riehle M. A., Garczynsiki S. F., CRIM J. W., Hill C. A., BROWN M. R., 2002. Neuropeptides and peptide hormones in Anopheles gambiae. Science 298, 172-175.

Roller L., YAMANAKA N., WatanaBe K., DAUBNEROVA I., ZITNAN D., KATAOKA H., TANAKA Y., 2008. The unique evolution of neuropeptide genes in the silkworm Bombyx mori. Insect Biochem. Mol. Biol. 38, 1147-1157.
SCHMIDT-NiELSEN K., 2008. Fizjologia zwierzat. Adaptacja do środowiska. Wydawnictwo Naukowe PWN, Warszawa.

SCHMitT F., VANSElOW J. T., SchlOSSER A., KaHNT J., Rössler W., WEGENER C., 2015. Neuropeptidomics of the carpenter ant Camponotus floridanus. J. Proteom. Res. 14, 1504-1514.

ScHOOFS L., NACHMAN R., 2006. Sulfakinins. [W:] Handbook of biologically active peptides. KASTIN A. J. (red.). Elsevier, Amsterdam, 183187.

SCHRADER M., SCHUlZ-KNAPPE P., FRICKER L. D., 2014. Historical perspective of peptidomics. EuPA Open Proteom. 3, 171-182.

SKÖLD K., 2006. Neuropeptidomics - methods and applications. Acta Universitatis Upsaliensis Digital Comprehensive Summaries of Uppsala Dissertations from the Faculty of Pharmacy, 42.

SŁOCIŃSKA M., MARCINIAK P., JARMUSZKIEWICZ W., RosińSKI G., 2015. New metabolic activity of the nonsulfated sulfakinin Zopat-SK-1in the insect fat body. Peptides 68, 157-163.

STARRAT A. N., BROWN B. E., 1975. Structure of the pentapeptide proctolin, proposed neurotransmitter in insects. Life Sci. 17, 12531256.

TAGHeRT P. H., Veenstra J. A., 2003. Drosophila neuropeptide signaling. [W:] Advances in genetics. HALl J. C., DUNLAP J. C., FRIEDMANN T. (red.). Elsevier, USA 49, 1-45.

Terhzaz S., Teets N. M., Cabrero P., Henderson L., Ritchie M. G., NACHMAN J. R., DOW J. A. T., Denlinger D. L., DAVIES S. A., 2015. Insect capa neuropeptides impact desiccation and cold tolerance. Proc. Natl. Acad. Sci. USA $112,2882-2887$

VAudRY D., Falluel-Morel A., Bourgault S., BASIlle M., Burel D., WurTZ O., FOURNIER A., ChOW B. K. C., Hashimoto H., Galas L., VAUDRY H., 2009. Pituitary adenylatecyclase-activating polypeptide and its receptors: 20 years after the discovery. Pharmacol. Rev. 61, 283-357.

Verleyen P., Huybrechts J., SAS F., Clynen E., BAgGerman G., DE LOOF A., Schoofs L., 2004, Neuropeptidomics of the grey flesh fly Neobellieria bullata. Biochem. Biophys. Res. Comm. 316, 763-770.

WASILEWSKI O., ROSIŃSKI G., 2007. Gonadoinhibitory effects of Neb-colloostatin and Neb-TMOF on ovarian development in the mealworm Tenebrio molitor L. Arch. Insect Biochem. Physiol. 64, 131-141.

Xu G., Gu G. X., Teng Z. W., Wu S. F., Huang J., SONG Q. S., YE G. Y., FANG Q., 2016. Identification and expression profiles of neuropeptides and their G-protein-coupled receptors in the rice stem borer Chilo suppressalis. Sci. Rep. 6, doi: 10.1038/srep28976.

Xu W., Song Q., Smith S. A., Chappell W. J., OUYANG Z., 2009. Ion trap mass analysis at high pressure: a theoretical view. J. Am. Soc. Mass Spectr. 20, 2144-2153.

YEW J. Y., WANG Y., BARTENEVA N., DikLER S., KUTZ-NABER K. K., Li L., KRAVITZ E. A., 2009. Analysis of neuropeptide expression and localization in adult drosophila melanogaster central nervous system by affinity cell-capture mass spectrometry. J. Proteom. Res. 8, 12711284.

Zatylny-Gaudin C., CORnet V., Leduc A., ZanutTini B., Corre E., LE CORguille G., BERnAY B., GaRderes J., Kraut A., COUTE Y., HENRY J., 2016. Neuropeptidome of the cephalopod Sepia officinalis: identification, tissue mapping 
and expression pattern of neuropeptides and neurohormones during egg-laying. J. Proteom. Res. 15, 48-67.

Zhang X., PetruZziello F., Rainer G., 2014. Extending the scope of neuropeptidomics in the mammalian brain. EuPA Open Proteom. 3, 273-279.
ZOEPHEL J., REIHER W., REXER K. H., KAHNT J., WEGENER C., 2012, Peptidomics of the agricurturally damaging larval stage of the cabbage root fly Delia radicum (Diptera: Anthomyiidae). PLoS One 7, e41543.

KOSMOS Vol. 67, 3, 597-611, 2018

\section{Patryk Nowicki, Monika Szymczak, Grzegorz Rosiński, Pawe€ Marciniak}

Department of Animal Physiology and Development, Institute of Experimental Biology, Faculty of Biology, Adam Mickiewicz University in Poznań, 89 Umultowska Str., 61-614 Poznań, E-mail: patryk.nowicki@amu.edu.pl

\section{THE NEUROPEPTIDOMICS OF INSECTS NEUROENDOCRINE SYSTEM}

\section{Summary}

Essential role in the regulation of all physiological processes and maintenance of homeostasis in the vast majority of animal organisms plays a neuro-endocrine system. So far, very well known to features are neuro-hormonal mediators regulating life processes of human. Over the last decade attention of researches has focused on identification and evaluation functions of insect neuropeptides and genes encoding them. In the present review, the structure and functions of insect neuro-endocrine system are characterized, the current state of knowledge on the difficulties and strategies in the neuropeptidomics research of these animals, with special emphasis on the use of mass spectrometry and the current rules of neuropeptides classification. Moreover, a list of known neuropeptidome insect species is presented, functional similarities between insect neuropeptides and their homologues occurring in vertebrates are defined and potential applications of research in the field of neuropeptidomics ewaluated. Available literature data suggest that neuropeptides so far identified in the insect model organism such as Drosophila melanogaster, may be used in the future to design a new generation of pharmaceuticals and bioinsecticides limiting the number of harmful insects from medical and economic point of view.

Key words: insects, neuro-endocrine system, neuropeptides, neuropeptidomics, mass spectrometry 